\title{
Biosafety and Removal Potential of Pollutants in Wastewater by the Microbial Flocculant from Marine Bacterium Obtained from Umlalazi Catchment, RSA
}

\author{
Zuzingcebo Goldern Ntombela ( $\sim$ NtombelaZG@unizulu.ac.za ) \\ University of Zululand Faculty of Science and Agriculture \\ AK Basson \\ University of Zululand Faculty of Science and Agriculture \\ E Madoroba \\ University of Zululand Faculty of Science and Agriculture \\ VSR Pullabhotla \\ University of Zululand Faculty of Science and Agriculture
}

\section{Research Article}

Keywords: B. safensis, biosafety, coal mine, domestic, flocculating activity, wastewater.

Posted Date: November 2nd, 2021

DOl: https://doi.org/10.21203/rs.3.rs-573736/v1

License: @ (i) This work is licensed under a Creative Commons Attribution 4.0 International License. Read Full License 


\section{Abstract}

Bioflocculants have been reported to be successfully used in the removal of pollutants and dye decolourization from wastewater as they (pollutants) have negative impact on both humans and aquatic life if not properly treated. Thus, the potential removal rate of a microbial flocculant produced by the marine bacterial strain of Bacillus safensis KX94275.1 from uMlalazi estuary, Mthunzini area, KZN for pollutants from wastewater samples and dyes from different dye solution was investigated. $B$. safensis produced a nontoxic microbial flocculant showed margin of safety in both breast cancer cells and normal cells with $87 \%$ and $96 \%$ cell survival after treatment with maximum dosage of bioflocculant solution of $100 \mu \mathrm{g} / \mu \mathrm{L}$, respectively. Functional groups such as amino, carboxylic and hydroxyl group were revealed with FT-IR spectrum to be possessed by the microbial flocculant produced. Above $65 \%$ of microbial flocculant was attained when the flocculant was subjection to $700^{\circ} \mathrm{C}$ using the thermogravimetric analyser. A produced bioflocculant was aqua-solvable and have no inhibitory effect in bacteria tested. This heat-stable and cation-dependent $\left(\mathrm{Ba}^{2+}\right)$ bioflocculant removed more than $85 \%$ dye from different dye solutions, such as basic fuchsine (93\%), congo red (87\%), crystal violet (90\%) and methylene blue (93\%), using $0.4 \mathrm{mg} / \mathrm{mL}$ optimum dosage concentration at neutral $\mathrm{pH}$. This wide $\mathrm{pH}$ (3-12) tolerant bioflocculant showed improvement on both domestic and coal mine wastewaters for the removal of biochemical oxygen demand with $66 \%$ and $99 \%$, chemical oxygen demand with $48 \%$ and $93 \%$, phosphate with $61 \%$ and $59 \%$, total nitrogen with $69 \%$ and $68 \%$ and sulphide with $71 \%$ and $83 \%$ removal rate, respectively, and flocculation rate of $91 \%$ (domestic) and $95 \%$ (coal mine) wastewater. Thus, the application of the bioflocculant on wastewater treatment indicated the tremendous prospective in replacing risky traditional flocculating agents frequently utilized for purification of wastewater.

\section{Introduction}

The population growth, economic growth and industrialization are major problems associated with environmental pollution and water scarcity worldwide. In many cases, industrial growth results in huge volumes of waste that eventually reach the reservoir if unprocessed. Universal expansion of industries generating waste is escalating and flattering the major concern for the ecosystem and regarded as the principal origin for aqua pollution (Naidoo \& Olaniran 2014). About $80 \%$ of infectious diseases in developing countries are associated with water pollution and billion people are without potable water (Siriwat and Tiedt 2019). Water borne diseases as well as cancer are among the most major roots for demise in growing nations, which are related to effluvium from industrial fields (Levy et al. 2018). Effluvium released improperly treatment into water bodies is a potential risk in the ecosystem and pollute the ecosystem (Rebah and Siddeeg 2017).

Fabric industrial fields employ large volumes of aqua together with synthetics during the textiles process. Most of the chemicals being utilized for textiles are composed of reagents that are diverse, ranging from organic substances to inorganic products and polymers (Tan et al. 2015). Reports show that more than 100 000 dyes are available commercially and over tonnes of dyes are annually generated by various industries (Tan et al. 2015). It is not easy to remove dyes from wastewater due to their synthetic and complex nature as a result of the different parameters including acidic, basic, structural changes, diazo, disperse, azo, metal complex and anthoquinone based dyes (Markandeya et al. 2017). These various factors make it impossible 
to remove the dyes from treatment of textile effluvium aerobically through municipal sewage treatment systems. This is due to the fact that municipal aerobic systems are dependent on biological activities, that are inefficient in the decolourization processes (Dlamini et al. 2019). The permeability to conventional treatment system of water soluble, brightly coloured, reactive and acidic dyes are the most common problems in wastewater treatment. Non-ionisable dyes in aqueous solution are said to be non-ionic. Almost all dyes are composed of aromatic substances and benzidine, therefore, resulting in cancer (Ardila-Leal et al. 2021).

Surface water has various substances that require to be eliminated before use as potable water. The substances required to be eliminated are categorized into settleable suspended solids, colloidal solids and dissolved solids (Naidoo \& Oloniran 2014). Thus, it needs to be treated thoroughly to remove these constitutes. Treatments mostly consist of flocculation, filtration and disinfection processes. Different techniques are used for water treatment that include chemical oxidation, physical separation, coagulation or flocculation, advanced oxidation, membrane separation, ion-exchange, incineration as well as purification (Liu 2016; Rajasulochana and Preethy 2016; Zajda and Aleksander-Kwaterczak 2019). Number of studies reported coagulation or flocculation as the most effectual and reliable technique in the removal of pollutants from effluent (Shi et al. 2018; Zhao et al. 2021). In this techniques, flocculants play a vital role by segregating the colloidal particles out of effluvium and removing dyes from wastewater via bridging, suspension enticement and ion counterbalance mechanisms (Lee et al. 2014). These flocculants are classified as chemical flocculants including aluminium salts and acrylamides as well as biological coagulants such as bioflocculants, tannin and cellulose (Zayed et al. 2019). Synthetic coagulants are extensively utilized for wastewater treatment due to efficacy, economical and high flocculation rate, but are harmful to humans and non-biodegradable in nature. Therefore, this has resulted into the researchers being interested in the use of biological flocculants, particularly the bioflocculants/ microbial flocculants (Sathiyanarayanan et al. 2013).

Recently, biological flocculants are trending as a replacement of chemical flocculants in the purification of effluvium as they are efficiency, biodegradable as well as innocuity as opposed to chemical flocculants (Sun et al. 2015). Number of industries have been profitably utilised biological flocculants, such as the treatment or removal of nutrients (Yan et al. 2020), BOD (Liu et al. 2021), pathogens (Okaiyeto et al. 2016), decolourization (Ray et al. 2019) and dense cations (Xiao et al. 2021). Presently, bioflocculants are more efficient in removing pollutants present in wastewater. Bioflocculants can easily eliminate organic pollutants, dyes, nutrients and pathogens (Shahadat et al. 2017).

Thus, the present study evaluated the ability for the microbial flocculant from Bacillus safensis in removing various pollutants including phosphate $\left(\mathrm{PO}_{4}{ }^{3+}\right)$, biological oxygen demand (BOD), total nitrogen $(\mathrm{N})$, sulphide $(\mathrm{S})$, and chemical oxygen demand (COD) from coal mine and domestic wastewater in comparison with traditional flocculants. The $B$. safensis bioflocculant was further tested for antimicrobial activity, biosafety, and its solubility effects.

\section{Experimental Section}

\section{Reagents and cultivation broth}


For this study, the chemicals and media utilized were obtained from Merck chemicals (Germiston, RSA). To produce a bioflocculant, the standard production medium by Karthiga Devi and Natarajan (2015) was used. The production broth made up of $0.5 \mathrm{~g}$ yeast extract, $0.5 \mathrm{~g}$ urea, $20 \mathrm{~g}$ D-glucose, $2 \mathrm{~g} \mathrm{KH}_{2} \mathrm{PO}_{4}, 5 \mathrm{~g} \mathrm{~K}_{2} \mathrm{HPO}_{4}, 0.2$ $\mathrm{g} \mathrm{MgSO}_{4}$ and $0.1 \mathrm{~g} \mathrm{NaCl}$ mixed with $1000 \mathrm{~mL}$ of sieved marine water. A solution was then autoclaved for 15 $\min$ at $121^{\circ} \mathrm{C}$.

\section{Source of bacteria}

Bacillus safensis bacterium was previously isolated from sediment and water samples of uMlalazi estuary, Mthunzini area, KZN, RSA. Nutrient broth supplemented with glycerol to a final concentration of $20 \%(\mathrm{v} / \mathrm{v})$ was utilized to keep the isolate and incubated at $-80^{\circ} \mathrm{C}$. Before the isolate was used, it was revived on nutrient broth and nutrient agar medium.

\section{Determination of bioflocculant production}

A loopful of $B$. safensis broth culture was transferred into a fermentation broth $(50 \mathrm{~mL})$ contained in $100 \mathrm{~mL}$ flask and then fermented at $28{ }^{\circ} \mathrm{C}$ for 3 days in a $160 \mathrm{rpm}$ agitation speed. The fermented production medium was spin at $8000 \mathrm{xg}$ for $15 \mathrm{~min}$ at $4{ }^{\circ} \mathrm{C}$ for the separation of microbial cells with supernatant. Supernatant was then used to measure the bioflocculation rate. The kaolin solution $(4 \mathrm{~g} / 1000 \mathrm{~mL})$ was used as a test material as described by Xia et al. (2018). An aqueous solution of kaolin clay (100 mL) in $150 \mathrm{~mL}$ container together with two millilitres of bioflocculant broth and three millilitres of $1 \%(w / v)$ Calcium chloride solution were shaken vigorously for $60 \mathrm{sec}$. The solution was transferred into a standing $150 \mathrm{~mL}$ graduated volumetric curve before rested for $5 \mathrm{~min}$ at room temperature. The analysis was done using the clear top liquid with a Pharo 300 spectrophotometer. Flocculation efficiency was measured using the equation below;

Flocculation rate $=[A-B] / A \times 100$,

Where $A$ is an absorbance of sample before treatment and $B$ as an absorbance of the sample after treatment recorded at $550 \mathrm{~nm}$.

\section{Production of pure microbial flocculant}

The pure microbial flocculant was obtained in accordance with Akapo et al. (2019) method. To extract the bioflocculant, the fermented production medium for 84 hrs containing a bioflocculant was centrifuged for 30 $\mathrm{min}$ at $4000 \mathrm{rpm}$ to get rid of bacterial cells. To supernatant, $2000 \mathrm{~mL}$ ice-cold alcohol were transferred and agitated vigorously before store at $4{ }^{\circ} \mathrm{C}$ for $12 \mathrm{hrs}$. The precipitate resulted was collected through centrifugation and vacuum-dried. The powder bioflocculant was re-dissolved in distilled water $(100 \mathrm{~mL})$ to form a solution. To purify the bioflocculant, suspension with a bioflocculant was blended with butanol in chloroform solution $(5: 2 \mathrm{v} / \mathrm{v})(100 \mathrm{~mL})$. The mixture was vigorously shaken and incubated overnight at room temperature. After centrifugation ( $8000 \mathrm{rpm}, 4^{\circ} \mathrm{C}, 15 \mathrm{~min}$ ) and freeze-drying the upper layer of the solution, a purified bioflocculant was attained.

\section{Chemical and physical characteristics of a pure bioflocculant}

The test material (kaolin particles), microbial flocculant and the mixture of kaolin particles and microbial flocculant were analyzed to obtain their surface structures. The surface structure was obtained using SEM- 
Sigma-VP-03-67 microscope equipped with an energy-dispersive X-ray analyzer (SEM-EDX) (OXFORD INSTRUMENT-X-MAX ${ }^{N}$ ) as described by Rasulov et al. (2017). The SEM images were obtained by placing small amount of bioflocculant in a silicon wrapped slide. The spin wrapper was used for fixing at $1000 \mathrm{rpm}$ for $1 \mathrm{~min}$. Fourier transform infrared (FT-IR) spectroscopy examinations were done in a microbial flocculant utilizing the Tensor 27 Bruker FT-IR spectrophotometer having a resolution of $4 \mathrm{~cm}^{-1}$ in the range of $4000-$ $400 \mathrm{~cm}^{-1}$ (Ntsangani et al. 2017). A thermogravimetric analysis (TGA) of a microbial flocculant was performed to analysis the thermal degradation using Perkin-Elmer Thermal Analysis Pyris 6 TGA (Ngema et al. 2020). To perform the analysis, bioflocculant powder sample (10 mg) was exposed at high temperatures ranging from 30 to $800^{\circ} \mathrm{C}$, at a constant rate of ramping, $10^{\circ} \mathrm{C} \mathrm{min}-1$ and under an inert atmosphere (nitrogen).

\section{Optimization of the purified bioflocculant in bioflocculation efficiency}

To obtain the optimum dosage concentration of a purified bioflocculant, different bioflocculant solutions were prepared in a range of $0.2-1.0 \mathrm{mg} / \mathrm{mL}$ and used to attain the optimum flocculating activity and the flocculating activities were measured as detailed above (Wan et al. 2013). A description of Yu et al. (2016) was used to determine the influence of $\mathrm{pH}$ on flocculation activity of the bioflocculant. $\mathrm{A} \mathrm{pH}$ range of 3-12 was used to adjust different kaolin solutions (0.4\% in distilled water) utilizing 1.0 N HCL and 1.0 N NaOH standard solutions and flocculation efficiencies were measured as described previously with $0.4 \mathrm{mg} / \mathrm{mL}$ as the excellent dosage amount. A synergistic influence by different cations on bioflocculation rate of the microbial flocculant was assessed in accordance to Ntombela et al. (2019). Three millilitres of various salts including monovalent, divalent and trivalent cations in concentrations of $1 \%(\mathrm{w} / \mathrm{v})$ replacing Calcium chloride were used. After which, the flocculating activity was determined as stated above. To prepare a control, the kaolin suspension and the bioflocculant solution were mixed with no metal ion added. The temperature influence on flocculation activity was also investigated in accordance with Zayed et al. (2019) description. Different temperatures between $50-100^{\circ} \mathrm{C}$ were used to heat various tubes with ten millilitres of the optimum microbial flocculant solutions for $30 \mathrm{~min}$ and the other tubes were autoclaved for $15 \mathrm{~min}$ at $121^{\circ} \mathrm{C}$. Following the method described above, the flocculating activity was determined.

\section{Dissolution assessment for microbial flocculant}

To investigate the microbial flocculant's ability to dissolve in various dissolvent, the method described by Maliehe et al. (2016) was followed. Hundred milligrams of a powdered microbial flocculant was dissolved in ten millilitres of various diluents including ethanol, hexane, benzene, distilled water, 2-propanone (acetone), methyl alcohol (methanol) and ethyl acetate.

\section{Biosafety analysis}

Both normal cells and cancerous cells were used to assess the cytotoxicity effect of the purified bioflocculant using 3-(4,5-dimethylthiozol-2-yl)-2,5-diphenyl tetrazolium bromide (MTT) assay in accordance with Daniels and Sign (2019). For cancerous cells analysis, the breast cancer (MFC 7) cells were used and human embryonic kidney (HEK 293) cells were used for normal cells assessment. Cell suspensions concentrated to $1 \times 10^{5}$ cell $/ \mathrm{mL}$ were cultivated in 48 well plates and incubated at $37^{\circ} \mathrm{C}$ overnight. Different concentrations of 
microbial flocculant solution were prepared in the range of $25-100 \mu \mathrm{g} / \mu \mathrm{L}$. After incubation, the broth was replaced with the sterile broth (MEM+Glutmax+antibiotics). Different concentrations of microbial flocculant solutions prepared were inoculated and incubated for $4 \mathrm{hrs}$ at $37^{\circ} \mathrm{C}$. After incubation, the medium used was replace by a complete solution consist of MEM+Glatmax+antibiotics $+10 \%$ fetal bovine serum and fermented for $48 \mathrm{hrs}$. After fermentation, the cells were mixed with $0.20 \mathrm{~mL}$ of 3-(4,5-dimethylthiozol-2-yl)-2,5-diphenyl tetrazolium bromide (MTT) solution concentrated to $5 \mathrm{mg} / \mathrm{mL}$ in phosphate buffered saline and incubated for $4 \mathrm{hrs}$ at $37^{\circ} \mathrm{C}$. Then, the solution was aspirated from the wells and dissolved in $0.1 \mathrm{~mL}$ of dimethyl sulfoxide (DMSO). The optical density (OD $570 \mathrm{~nm}$ ) of the medium was recorded with a microplate reader. Formula below was utilized to estimate the cell survival (\%):

$\%$ Cell inhibition $=\mathrm{B}_{1} / \mathrm{B}_{2} * 100$

Where $B_{1}$ is the value of cells treated and $B_{2}$ is the value of untreated cells with bioflocculant.

\section{Analysis of antimicrobial potential}

About one thousand microliters of Bacillus cereus, Bacillus subtilis, Klebsiella pneumoniae and Escherichia coli broth cultures were used to investigate the antimicrobial potential of a bioflocculant. Before used, all strains were revived by inoculating them in freshly prepared and decontaminated nutrient broth and grown at $37^{\circ} \mathrm{C}$ overnight. Thereafter, the optical density of the strains was adjusted to 0.5 (McFarlan standard) with spectrophotometer at $600 \mathrm{~nm}$. To investigate the Minimum inhibitory concentration, 96 well plates technique was used with $40 \%$ Ciprofloxacin and deionized water as the standards (Dlamini et al. 2020b). The entire micro-wells were filled with $50 \mu \mathrm{L}$ of freshly prepared nutrient broth and $50 \mu \mathrm{L}$ of each strain. About $50 \mu \mathrm{L}$ of $0.4 \mathrm{mg} / \mathrm{mL}$ bioflocculant solution was introduced in the initial rows of 96 micro-well plates and the serial dilutions were made from the highest dilution to the lowest to make sure that all remained with $50 \mu \mathrm{L}$. Afterwhich, an indicator, P-iodinitrotetrazolium (INT) $(40 \mu \mathrm{L})$, concentrated to $0.2 \mathrm{mg} / \mathrm{mL}$ was introduced. The colour change was observed after the plates were incubated for half an hour at $37^{\circ} \mathrm{C}$.

\section{Decolourization of various dye solutions}

To test for decolourization ability of the bioflocculant, $100 \mu \mathrm{L}$ of microbial flocculant broth $(0.4 \mathrm{mg} / \mathrm{mL})$ was transferred into $50 \mathrm{~mL}$ of dye medium $(4 \mathrm{~g} / 1000 \mathrm{~mL})$ and $1.3 \mathrm{~mL}$ of $\mathrm{BaCl}_{2}(1 \% \mathrm{w} / \mathrm{v})$ was added. Experimental dyes such as basic fuchsine, congo red, crystal violet and methylene blue were used. The mixture of dye, bioflocculant and Barium chloride solutions was agitated vigorously and sedimented for $10 \mathrm{~min}$. Afterwhich, the supernatants were taken and analysed using a spectrophotometer (Pharo 300, Merck KGaA, Germany) at the highest wavelength for each dye tested. The decolourization potential of the bioflocculant was calculated using the equation below:

Removal efficiency $=R_{i}-R_{f} / R_{i} * 100$

Where $\mathrm{R}_{i}$ is a value of untreated stain broth and $\mathrm{R}_{f}$ is a value of treated stain broth with a bioflocculant (Chen et al. 2017).

Removal efficiency of the bioflocculant on wastewater 
Coal mine and domestic effluvium samples were utilized to investigate the removal ability of the bioflocculant. To assess the removal ability of pollutants in all wastewater samples as described by Ntombela et al. (2019), from each sample $50 \mathrm{~mL}$ of wastewater sample was poured into $250 \mathrm{~mL}$ conical flask followed by the addition of $1.5 \mathrm{~mL}$ Barium chloride solution $(1 \% \mathrm{w} / \mathrm{v})$ together with $1.0 \mathrm{~mL}$ bioflocculant solution. The supernatant was used to measured the removal efficiencies of total nitrogen $(N)$, sulphide $(S)$, chemical oxygen demand (COD), phosphate $\left(\mathrm{PO}_{4}{ }^{3+}\right.$ ) and biochemical oxygen demand (BOD) after the solution was agitated and sedimented. The values (RE) were measured for the samples prior to flocculation and after flocculation utilizing test kits in accordance with the manufacture's protocol and Pharo 300 spectrophotometer (Merck KGAa, Germany) at a wavelength of $680 \mathrm{~nm}$. The obtained values were compared with the values of two commercial flocculants (Alum and $\mathrm{FeCl}_{2}$ ) replacing the bioflocculant. The removal efficiencies were calculated as follows:

$\operatorname{RE}(\%)=P_{0}-P_{i} / P_{0} * 100$

Where: $\mathrm{P}_{\mathrm{o}}$ is an initial value and $\mathrm{P}_{\mathrm{i}}$ is the value of the flocculated sample.

\section{Experimental, software and statistical analysis}

The data was collected and recorded in triplicates. The error bars in the figures show the standard deviations of the data. Data was subjected to One-way analysis of variance utilizing Graph Pad Prism ${ }^{\mathrm{TM}}$ 6.1. Values with various alphabets show significant differences at $p \leq 0.05$.

\section{Results And Discussion}

\section{Characterization of a bioflocculant}

Functional groups account for adsorption sites of flocculants for colloids in suspension (Ntozonke 2015). The multiple functional groups indicate the number of adsorption sites for colloidal particles. The bioflocculant by Bacillus safensis revealed with IR spectrum to possess various functional groups such as hydroxyl signalled with an absorption peak at $3303 \mathrm{~cm}^{-1}$ carbonyl represented by a small absorption peak at $1666 \mathrm{~cm}^{-1}$ and amine groups shown overlapping with hydroxyl $(\mathrm{O}-\mathrm{H})$ at stretching peak at $3303 \mathrm{~cm}^{-1}$ which are principal functional groups found inside the microbial flocculant's binding sites accountable for flocculation process (Figure 1a). Thermal stability of the bioflocculant produced by $B$. safensis was investigated using TG analyser. TG analysis was performed to institute the devolatilization description of the produced bioflocculant. From the analysis, three phases were noticed for the produced bioflocculant. The initial phase was observed between $29-100^{\circ} \mathrm{C}$ with around $7 \%(\mathrm{w} / \mathrm{w})$ weight loss owing to water content dissipation. Another weight loss was observed between $150-200{ }^{\circ} \mathrm{C}$ with weight loss of $15.54 \%$ accounts for moisture content loss. The last phase was observable in higher temperatures where the weight loss of $33.20 \%$ $(w / w)$ was confirmed for the bioflocculant due to the decomposition of the bioflocculant (Figure 1b).

The surface morphological structures of the flocculants have the essential roles in the process of flocculation (Akapo et al. 2019). The SEM analysis of the bioflocculant, kaolin particles and flocculated kaolin particles was investigated and the results are shown in Figure 6.2. SEM images (Figure 6.2) show the crystal-like facet 
patterning framework of the microbial flocculant (Figure 2a), fine as well as scattered appearance for kaolin particles (Figure 2b) and very big flocs for flocculated kaolin particles (Figure 2c) that are easily precipitate due to gravity. SEM-EDX analysis showed the elements present in the purified bioflocculant in mass proportion (\% w/t) such as C (19.0), N (1.0), O (48.8), Na (0.7), Mg (2.7), P (7.2), S (0.1), Cl (0.7), Si (5.5), Al (5.5), K (1.0) and $\mathrm{Ca}$ (7.3) (Ntombela et al. 2020) which are accountable for the flexibility and stability of the bioflocculant.

\section{Flocculation properties of the microbial flocculant from B. safensis}

In bioflocculation, optimization of the microbial flocculant conditions is essential to improve its flocculation efficiency. Insufficient dosage concentration of microbial flocculant fails to adequately counterbalance certain negative charges present in suspended colloids leading to poor flocculation rate (Selepe 2017). Excessive bioflocculant dosages adversely influence the sedimentation and stabilization of the flocs owing to the escalated viscidity (Okaiyeto et al. 2015). Bacillus safensis produced a bioflocculant which preferred the 0.4 $\mathrm{mg} / \mathrm{mL}$ dosage concentration for its optimum flocculating activity (Figure 3a). The dosage concentrations below and above $0.4 \mathrm{mg} / \mathrm{mL}$ inhibited the flocculating activity of the bioflocculant (Ntombela et al. 2020).

Cations have a significant function in the flocculation reaction as they enhance the neutralization and stabilization rate of the functional groups in the molecular chain of the microbial flocculant and kaolin particles resulting in the improved flocculating activity (Ayangbenro and Babalola 2018). Bacillus safensis produced a bioflocculant which preferred the $\mathrm{Ba}^{2+}$ as a stimulating agent for the optimum flocculating activity among others tested (Figure $3 \mathrm{~b}$ ). $\mathrm{pH}$ is one of the essential parameters in the reaction mixture due to its effect on the surface charge and electrification condition of bioflocculants and suspended colloids and therefore possess a substantial effect on the flocculation efficiency (Sun et al. 2015). In Figure 3(c), the flocculation rate showed by the microbial flocculant from $B$. safensis was hugely influenced by the $\mathrm{pH}$ of the kaolin solution. Bacillus safensis produced the bioflocculant favoured by alkaline, neutral and acidic conditions for great flocculating activity greater than $70 \%$ with an optimum flocculating activity of $91 \%$ at $\mathrm{pH}$ 11 (Ntombela et al. 2020).

The bioflocculant exhibited thermal stability properties as it retained over $55 \%$ flocculating activity when exposed to high temperatures. The thermal behaviour of the bioflocculant is in line with the existence of functional groups such as carboxylic and hydroxyl groups within the bioflocculant that might have permitted the hydrogen bonds formation. This indicates that the bioflocculant has got the carbohydrates as a backbone and less protein content is available (Figure 3d) (Ntombela et al. 2020).

\section{Solubility assay of the bioflocculant}

Bioflocculant compounds are not the same in the stability of charged, polar and hydrophobic constituents they possess on their outer membranes. The bioflocculant produced by Bacillus safensis was assessed for its solubility effect towards various dissolvent including methyl alcohol (methanol), hexane, ethyl acetate, ethanol, distilled water, benzene and dimethyl ketone (acetone). Only the distilled water was able to dissolve the bioflocculant completely among other tested dissolvent. The availability of carbohydrates component in the molecular chain has a significant character in the solubility effect of the bioflocculant. The microbial 
flocculants having polysaccharides as the dominant components are more of hydrophilic fraction compared to hydrophobicity nature of the bioflocculants with proteins as major components (More et al. 2014). The bioflocculant in this study was revealed to be predominately a polysaccharide (Ntombela et al. 2020), thus, the bioflocculant possesses charged and polar groups that are simply dissolved by water particles and eventually making the bioflocculant dissolvable and have a strong affinity of water.

Solubility of the bioflocculants could be explained based on the protein and carbohydrates content which is related to their stability towards different solvents treated. According to Maliehe et al. (2016), bioflocculants are likely to completely dissolve in water and in acidic and basic media. This bioflocculant has been revealed through FT-IR spectrum to have hydroxyl groups in its structure (Ntombela et al. 2020), which has been linked with strong attraction forces between bioflocculant molecules, resulting in the development of very strong crystalline solids leading to the occurrence of the rigid hydrogen bonding. Other solvents than water were incapable to dissociate these forces and the bioflocculant failed to dissolve in all of the organic solvents tested. Therefore, for the bioflocculant to completely dissolve in water or aqueous medium it must have $\mathrm{OH}-$ functional groups in their molecular chain in order to form hydrogen bonding with water molecules (Okaiyeto et al. 2015). This behaviour shown by the bioflocculant from B. safensis to dissolve in distilled water or aqueous solution only has been documented by numerous authors including Zaki et al. (2011) and Bisht and Lal (2019).

\section{Antimicrobial activity assay of a bioflocculant}

Bacillus subtilis, Escherichia coli, Bacillus cereus and Klebsiella pneumoniae are the microorganisms used in the assessment of the antimicrobial activity potential of the bioflocculant in comparison with the antibiotic (Ciprofloxacin). MIC tests conducted revealed that microorganisms investigated managed to grow optimally in the presence of the bioflocculant, but their growth was inhibited when the Ciprofloxacin was used. Only the antibiotic used has an inhibitory effect on all tested microorganisms and the bioflocculant was observed to exhibit no inhibitory properties over all tested microorganisms. Bioflocculants are thought to remove microbes with flocs during the bioflocculation process where the microorganisms settle down together with the flocs being formed as opposed to block their cell multiplication (Ntombela et al. 2021a). Although bioflocculants have been documented to block the growth of microorganisms, there is less information regarding their mechanism of action on the removal of pathogens in wastewater has been documented. Bacteria can attach to the suspended particles or kaolin particles and eventually collected together with the flake-like substances generated. Ciprofloxacin (positive control) inhibited the growth of all tested bacteria with the lowest concentrations of $6.25 \mathrm{mg} / \mathrm{mL}$ (Escherichia coli), $3.125 \mathrm{mg} / \mathrm{mL}$ (Bacillus cereus \& Bacillus subtilis) and 1.56 $\mathrm{mg} / \mathrm{mL}$ (Klebsiella pneumoniae). The smallest dosage amount of $1.56 \mathrm{mg} / \mathrm{mL}$ was more than enough to inhibit the microbial growth for Klebsiella pneumonia bacterium. Some researchers have reported various bioflocculants to eliminate microorganisms from wastewater. For example, Klebsiella pneumoniae produced a microbial flocculant capable of removing the Acanthamoeba cysts present in contaminated water (Zhao et al. 2013) and Dlamini et al. (2020a) reported the bioflocculant passivated in Fe@Cu core-shell nanoparticles to remove both Gram-negative and Gram-positive microorganisms from wastewater.

\section{Cytotoxicity effect on HEK 293 and MFC 7 cell-lines}


Cytotoxicity experiments of microbial flocculant on the HEK 293 and MFC 7 cell lines were carried out using MTT assay (Moodley and Singh 2019) and the resulted are shown in Figure 4. Although bioflocculants have been reported to be non-toxic by numerous researchers but there is a necessity to assess their cytotoxicity prior to their utilization for biosafety reasons as some bioflocculants may exhibit toxic effect (Maliehe et al. 2019). In this study, the bioflocculant revealed a margin of safety with above $95 \%$ viability of normal cells (HEK 293) exhibited in all evaluated bioflocculant concentrations. At the lowest bioflocculant concentration $(25 \mu \mathrm{g} / \mu \mathrm{L})$, no cell inhibition has been observed with an average of $100 \%$ cell survival and $96 \%$ viability when the cells were subjected to the maximum dosage of $100 \mu \mathrm{g} / \mu \mathrm{L}$ (Figure 4a). Cancerous cells (MFC 7) showed no cell inhibition as $100 \%$ cell survival has been observed at the lowest concentration $(25 \mu \mathrm{g} / \mu \mathrm{L}) \mathrm{used}$ (Figure 4b). About $90 \%$ cell survival was obtained when the maximum bioflocculant dosage was used which is little bit less compared to the smallest bioflocculant dosage concentration. Therefore, the bioflocculant produced by $B$. safensis has demonstrated a good safety property that could be safe for application in different industrial reactions. Other authors also reported the microorganisms to produce non-toxic bioflocculants including Sharma et al. (2017) reported the toxic-free bioflocculant produced by Acinetobactor haemolyticus against sheep blood cells and in the in-vivo study on rats, no toxicity effects were reported. Maliehe et al. (2020) also reported a non-toxic microbial flocculant tested on HEK 293 cell line.

\section{Dye removal by bioflocculant}

Wastewater that contains dyes is a major concern globally, for industries that produce these wastewater, including paper and pulp, food, textile and leather. These dyes have negative effects towards human beings, microorganisms and aquatic-dependent matters (Yang et al. 2013). Aljeboree et al. (2017) reported that dyes are tetragenic, carcinogenic, mutagenic and occasionally recalcitrant to microbial degradation. Fabric industrial fields are known to generate large volumes of effluvium containing toxic materials, which eventually entering water bodies when not treated. Therefore, the microbial flocculant produced by Bacillus safensis was also investigated in this study, for its ability to remove dyes from different solutions and findings are shown in Figure 4c. More than $80 \%$ of the dye removal potential was revealed by the microbial flocculant in the entire dyes tested. In congo red, high removal efficiency (94\%) was observed, followed by $93 \%$ for basic fuchsine, $90 \%$ methylene blue, and the lowest removal efficiency of $87 \%$ for crystal violet. Other bioflocculants were also reported to remove dyes from wastewater including the bioflocculant produced by Bacillus sp. (Ntombela et al. 2021b) and the microbial strains Xn11 and Xn7 produced the microbial flocculant reported to successfully remove colour from carbol fuchsine medium with more than $90 \%$ removal rate and less than 40\% removal ability shown for reactive black dye from the solution (Zhang et al. 2012).

\section{Wastewater treatment using a bioflocculant}

Table 1 and Table 2 show the ability of the bioflocculant from Bacillus safensis to remove various contaminants available in domestic (Vulindlela Township, KwaZulu-Natal) and coal mine wastewater (Tendele coal mine, Mtubatuba, KwaZulu-Natal) in comparison with alum and ferric chloride. Excessive amount of pollutants such as COD and BOD does not support aquatic life (Verma et al. 2012). Nutrients in excess including nitrogen, phosphate and sulphur in water promote eutrophication. Nitrates and nitrogen have been considered as the huge threat in aquatic life as they lead to eutrophophication and eventually influence the cost of the availability of potable water. The availability of phosphate in water encourages the growth of 
marine plants and plankton, which avail food for fish. This increase in growth may increase the population growth of fish and enhance overall water quality. But the excessive amount of phosphate may result in wild growth of plants and algal in water leading to the eutrophication or excessive fertilization of receiving waters. Over fertilization may lead to the decay of vegetation and quality of life owing to lowered dissolved oxygen standards. High levels of phosphate may lead to phosphate toxicity in both humans and animals (Komaba and Fukagawa 2016). Therefore, it is of importance to remove them from water. The application of bioflocculant for the removal of these pollutants from industrial wastewater and domestic wastewater was investigated in comparison with traditional flocculants. The bioflocculant had a better removal efficiency of COD (48\%) and BOD (68\%) present in domestic wastewater compared to traditional flocculants (Table 1). The produced bioflocculant had effectively removed total nitrogen, sulphide, phosphate and turbidity from domestic wastewater with removal efficiencies of $69 \%, 71 \%, 61 \%$ and $91 \%$, respectively. The removal rate for the tested pollutants by bioflocculant is very comparable and even better than that of harmful chemical flocculants used in the experiments.

The microbial flocculant potential to remove various pollutants from coalmine effluvium was also assessed and compared with commercial flocculants (Table 2). The bioflocculant showed better removal efficiencies of COD (93\%), BOD (99\%), total nitrogen (68\%), sulphide (83\%) and phosphate $(59 \%)$ and the flocculating activity of $95 \%$ as opposed to less than $65 \%$ (COD and BOD), an average $61 \%$ (total nitrogen) and less than $80 \%$ (sulphide) for both chemical flocculants used. In general, the ability of the bioflocculant to remove pollutants was attributed to its surface structure, chemical components and functional groups. The effectiveness illustrated by the bioflocculant implied that it has potential to be used in wastewater treatment especially in industrial wastewater in replacing the currently predominant traditional flocculants. Similar results were also reported where the bioflocculant from Bacillus sp. was capable of efficiently reducing various pollutants in wastewater better than the traditional flocculants (Ntombela et al. 2021b). Maliehe et al. (2020) also reported the bioflocculant from the consortium to remove the pollutants in wastewater better that chemical flocculants. The bioflocculant from mixed culture of Bacillus safensis and Bacillus sp. showed better removal rate of different pollutants in wastewater samples (Ntombela et al. 2021a). 
Table 1

Removal of pollutants from domestic wastewater by a bioflocculant

\begin{tabular}{|c|c|c|c|c|c|c|c|}
\hline Flocculants & $\begin{array}{l}\text { Quality of } \\
\text { water }\end{array}$ & $\begin{array}{l}\text { BOD } \\
(\mathrm{mg} / \mathrm{L})\end{array}$ & $\begin{array}{l}\text { COD } \\
(\mathrm{mg} / \mathrm{L})\end{array}$ & $\begin{array}{l}\text { Nitrogen } \\
\text { (mg/L) }\end{array}$ & $\begin{array}{l}\text { Sulphide } \\
\text { (mg/L) }\end{array}$ & $\begin{array}{l}\text { Phosphate } \\
\text { (mg/L) }\end{array}$ & $\begin{array}{l}\text { Flocculation } \\
\text { efficiency @ } \\
\text {ODD }_{680 \mathrm{~nm}}\end{array}$ \\
\hline \multirow[t]{3}{*}{ Bioflocculant } & Untreated & 38 & 404 & 0.137 & 0.85 & 3.38 & 0.395 \\
\hline & Treated & 12 & 210 & 0.043 & 0.25 & 1.33 & 0.035 \\
\hline & $\begin{array}{l}\text { Flocculation } \\
\text { rate (\%) }\end{array}$ & 68 & 48 & 69 & 71 & 61 & 91 \\
\hline \multirow[t]{3}{*}{ Iron(III)chloride } & Untreated & 38 & 404 & 0.137 & 0.85 & 3.38 & 0.395 \\
\hline & Treated & 24 & 251 & 0.059 & 0.27 & 1.06 & 0.089 \\
\hline & $\begin{array}{l}\text { Flocculation } \\
\text { rate (\%) }\end{array}$ & 37 & 38 & 57 & 68 & 69 & 78 \\
\hline \multirow[t]{3}{*}{ Alum } & Untreated & 38 & 404 & 0.137 & 0.85 & 3.38 & 0.395 \\
\hline & Treated & 25 & 231 & 0.057 & 0.35 & 0.99 & 0.083 \\
\hline & $\begin{array}{l}\text { Flocculation } \\
\text { rate (\%) }\end{array}$ & 34 & 43 & 58 & 59 & 71 & 79 \\
\hline
\end{tabular}

NB: Values are means of triplicates data.

Table 2

Removal efficiency of pollutants in coalmine wash water

\begin{tabular}{|c|c|c|c|c|c|c|c|}
\hline $\begin{array}{l}\text { Flocculating } \\
\text { agents }\end{array}$ & $\begin{array}{l}\text { Quality of } \\
\text { water }\end{array}$ & $\begin{array}{l}\text { BOD } \\
(\mathrm{mg} / \mathrm{L})\end{array}$ & $\begin{array}{l}\text { COD } \\
(\mathrm{mg} / \mathrm{L})\end{array}$ & $\begin{array}{l}\text { Nitrogen } \\
\text { (mg/L) }\end{array}$ & $\begin{array}{l}\text { Sulphide } \\
\text { (mg/L) }\end{array}$ & $\begin{array}{l}\text { Phosphate } \\
\text { (mg/L) }\end{array}$ & $\begin{array}{l}\text { Flocculation } \\
\text { rate @ } 680 \\
\text { nm }\end{array}$ \\
\hline \multirow[t]{3}{*}{ Bioflocculant } & Untreated & 58 & 1557 & 7.2 & 0.90 & 2.00 & 1.936 \\
\hline & Treated & 0.74 & 116 & 2.30 & 0.15 & 0.83 & 0.098 \\
\hline & $\begin{array}{l}\text { Flocculation } \\
\text { rate (\%) }\end{array}$ & 99 & 93 & 68 & 83 & 59 & 95 \\
\hline \multirow[t]{3}{*}{ Iron(III)chloride } & Untreated & 58 & 1557 & 7.2 & 0.90 & 2.00 & 1.936 \\
\hline & Treated & 27 & 150 & 2.9 & 0.19 & 0.50 & 0.139 \\
\hline & $\begin{array}{l}\text { Flocculation } \\
\text { rate (\%) }\end{array}$ & 53 & 90 & 60 & 79 & 75 & 93 \\
\hline \multirow[t]{3}{*}{ Alum } & Untreated & 58 & 1557 & 7.2 & 0.90 & 2.0 & 1.936 \\
\hline & Treated & 21 & 276 & 2.82 & 0.27 & 0.38 & 0.278 \\
\hline & $\begin{array}{l}\text { Flocculation } \\
\text { rate (\%) }\end{array}$ & 64 & 82 & 61 & 70 & 81 & 85 \\
\hline
\end{tabular}




\section{Conclusion}

The thermostable polysaccharide-bioflocculant produced by Bacillus safensis revealed to have hydroxyl, carboxylic and amino functional groups responsible for settling down of suspended particles, colloids and other pollutants to form flocs. The bioflocculant showed remarkable flocculation potential with the bioflocculant concentration size of $0.4 \mathrm{mg} / \mathrm{mL}$. It is a cation-depended bioflocculant that functions very well

when $\mathrm{Ba}^{2+}$ was used as a stimulating agent. The water-soluble bioflocculant showed less growth inhibition towards the tested microorganisms. The excellent flocculation of this bioflocculant is related with its crystallike structure revealed through SEM analysis. The non-toxic microbial flocculant demonstrated the exceptional characteristics for flocculation, pollutants removal in domestic and coal mine wastewater as well as the removal of dyes from various dye solutions. The removal efficiencies of up to $93 \%$ for COD and $99 \%$ for BOD were obtained in both domestic and coal mine wastewaters which are better when compared to both conventional flocculants used. In addition, more than $90 \%$ of turbidity removal rate was shown by bioflocculant. The bioflocculant demonstrated great potential in removing various pollutants from wastewater samples treated. These pollutants include total nitrogen, sulphide and phosphate with removal efficiencies more than $65 \%, 67 \%$ and $58 \%$, respectively. These removal rates are comparable to frequently used traditional flocculants. The bioflocculant functions very well in a wide range of $\mathrm{pH}$ and showed interesting removal potential of dyes from various dye solutions tested with the removal efficiency above $85 \%$ for all tested dye solutions. The produced bioflocculant has the potential to be used in water purification to replace hazardous conventional coagulants, especially in domestic and industrial wastewater treatment.

\section{Declarations}

\section{Conflict of interest}

No conflict of interest was declared by the authors in this study.

\section{Acknowledgement}

The principal author acknowledges the Research \& innovation Committee, Bioflocculant Group and the staff (Department of Biochemistry and Microbiology) of the University of Zululand for the support they received. Prof VSRR Pullabhotla acknowledges National Research Foundation (NRF, RSA) for supporting the study financially in the form of Incentive Fund Grant (Grant number 103691).

\section{Author contributions}

Conceptualization: AKB, VSRP and EM; formal analysis: ZGN \& VSRP; investigation: ZGN; supervision: AKB, VSRP \& EM; writing (original draft: ZGN; writing (review and editing): AKB, VSRP, EM \& ZGN.

\section{References}

1. Akapo CSO, Ntombela ZG, Pullabhotla VSR, Basson AK (2019) Isolation, optimization, characterization and application of bioflocculant BA-CGB produced by novel Bacillus atrophaeus isolated from Richards Bay Harbour, South Africa. Biosci Res 16(4): 3873-3902 
2. Aljeboree AM, Alshirifi AN, Alkaim AF (2017) Kinetics and equilibrium study for the adsorption of textile dyes on coconut shell activated carbon. Ara J Chem 10: 3381-3393

3. Ardila-Leal LD, Poutou-Piñales RA, Pedroza-Rodríguez AM, Quevedo-Hidalgo BE (2021) A brief history of colour, the environmental impact of synthetic dyes and removal by using Laccases. Mol 26: 1-40

4. Ayangbenro AS, Babalola OO (2018) Metal(loid) bioremediation: strategies employed by microbial polymers. Sustain 10(3028): 1-14

5. Bisht V, Lal B (2019) Exploration of performance kinetics and mechanism of action of a potential novel bioflocculant BF-VB2 on clay and dye wastewater flocculation. Front Microbiol 10(1288): 1-18

6. Chen Z, Li Z, Peize Liu, Liu Y, Wang Y, Li Q, He N (2017) Characterization of a novel bioflocculant from a marine bacterium and its application in dye wastewater treatment. BMC Biotechnol 17(84): 1-11

7. Daniels AN, Singh M (2019). Sterically stabilized siRNA: gold nanocomplexes enhance c-MYC silencing in a breast cancer cell model. Nanomed. 14(11): 1387-1401

8. Dlamini NG, Basson AK, Pullabhotla VSR (2019). Optimization and application of bioflocculant passivated copper nanoparticles in the wastewater treatment. Int J Environ Res Pub Health 16(2185): 115

9. Dlamini NG, Basson AK, Pullabhotla VSR (2020a) Application and biosafety of the Fe@Cu core-shell nanoparticles. South African J Sci Technol 39(1): 78-84

10. Dlamini NG, Basson AK, Pullabhotla VSR (2020b) Wastewater treatment by a polymeric bioflocculant and iron nanoparticles synthesized from a bioflocculant. Polymer 12(7): 1618-1631

11. Karthiga D, Natarajan KA (2015) Isolation and characterization of a bioflocculant from Bacillus megaterium for turbidity and arsenic removal. Min \& Metal Proc 32 (4): 222-229

12. Komaba H, Fukagawa M (2016) Phosphate-a poison for humans? Kidn Intern 90(4): 753-763

13. Lee SR, John F, Mei C. Chong B (2014) A review on application of flocculants in wastewater treatment. Proc Safety Environ Protect 92: 489-508

14. Levy K, Smith SM and Carlton EJ (2018) Climate change impacts on waterborne diseases: Moving toward designing interventions. Curr Environ Health Rep 5(2): 272-282

15. Liu Y (2016) Advanced treatment of biologically treated heavy oil wastewater for reuse as boiler feedwater by combining ultrafiltration and nanofiltration. Desalin Water Treat 57 (2016): 13113-13119

16. Liu C, Sun D, Liu J, Zhu J, Liu W (2021) Recent advances and perspectives in efforts to reduce the production and application cost of microbial flocculants. Bioresour Bioproc 8(51): 1-20

17. Maliehe TS, Selepe NT, Ntombela ZG, Simonis JJ, Basson AK, Ngema S, Xaba PS, Mpanza FL (2016) Production and characteristics of bioflocculant TPT-1 from a consortium of Bacillus pumilus JX860616 and Alcaligenes faecalis HCB2. Afr J Microbiol 10(37): 1561-1575

18. Maliehe TS, Basson AK, Dlamini NG (2019). Removal of Pollutants in Mine Wastewater by a NonCytotoxic Polymeric Bioflocculant from Alcaligenes faecalis HCB2. Int J Environ Res Public Health 16(20): 1-17

19. Maliehe TS, Basson AK, Singh M (2020) Wastewater treatment by a novel bioflocculant from a consortium of Bacillus pumilus JX860616 and Bacillus subtilis CSM5. Biosci Res 17(3): 1610-1625 
20. Markandeya S, Shukla SP, Mohan D (2017) Toxicity of disperse dyes and its removal from wastewater using various adsorbents: a review. Res J Environm Toxicol 11: 72-89

21. Moodley T, Singh M (2019) Polymeric mesoporous silica nanoparticles for enhanced delivery of 5Fluorouracil in vitro. Pharmac 11: 288

22. More TT, Yadav JSS, Yan S, Tyagi RD, Surampalli RY (2014) Extracellular polymeric substances of bacteria and their potential environmental applications. J Environ Manag 144: 1-25

23. Naidoo S, Olaniran A (2014) Treated wastewater effluent as a source of microbial pollution of surface water resources. Int J Environ Res Publ Heal 11: 249-270

24. Ngema SS, Basson AK, Maliehe TS (2020) Synthesis, characterization and application of polyacrylamide grafted bioflocculant. Phys Chem Eart 115(102821): 1-11

25. Ntozonke N (2015) Assessment of bioflocculant production by two marine bacteria isolated from the bottom sediment of marine Algoa Bay. Master of Science (Microbiology) Thesis, Department of Biochemistry and Microbiology, Faculty of Science and Agriculture, University of Fort Hare, Alice, South Africa

26. Ntombela ZG, Mthembu NS, Gasa NL, Basson AK, Simonis JJ, Madoroba E, Pullabhotla VSR (2019) Isolation, identification and characterization of a bioflocculant producing strain, Bacillus sp. KC782848.1, from uMlalazi catchment, Mtunzini, KwaZulu-Natal. Biosci Res 16(4): 3664-3685

27. Ntombela ZG, Kubhayi TM, Basson AK, Simonis JJ, Madoroba E, Pullabhotla VSRR (2020) Characterization of bioflocculant produced by Bacillus species isolated from uMlalazi estuary, Mthunzini area (KwaZulu-Natal) and its application in wastewater treatment. Biosci Res J Innov Scientif Info Serv Netw 17(3): 1944-1970

28. Ntombela ZG, Basson AK, Madoroba E, Pullabhotla VSRR, Moganavelli S (2021a) Removal efficiency of a thermostable and non-toxic bioflocculant produced by a consortium of two marine bacteria. Biosci Res (18(1): 188-207

29. Ntombela ZG, Basson AK, Madoroba E, Pullabhotla VSRR (2021b) Pollutants removal from acidic coal mine wastewater using the non-toxic glycoprotein extracellular polymeric substance from Bacillus Sp. Biosci Res 18(2): 1733-1751

30. Ntsangani N, Okaiyeto K, Nwodo UU, Olaniran AO, Mabinya LV, Okoh Al (2017) Bioflocculation potentials of a uronic acid- containing glycoprotein produced by Bacillus sp. AEMREG 4 isolated from Thyme river, South Africa. Biotechnol 7(78): 1-35

31. Okaiyeto K, Nwodo UU, Mabinya LV, Okoh Al (2015) Characterization and flocculating properties of a biopolymer produced by Halomonas sp. Okoh. Water Environ Res 87: 298-303

32. Okaiyeto K, Nwodo UU, Okoli SA, Mabinya LV, Okoh Al (2016) Implications for public health demands alternatives to inorganic and synthetic flocculants: bioflocculants as important candidates. J Microbiol 5(2): 177-211

33. Rajasulochana P, Preethy V (2016) Comparison on efficiency of various techniques in treatment of waste and sewage water - a comprehensive review. Resour Effic Technol 2(4): 175-184

34. Rasulov BA, Li, Liu Y-H, Mahammed OA, Xiao M, Ma J-B, Li W-J (2017) Production, characterization and structural modification of exopolysaccharide-based bioflocculant by Rhizobium radiobacter SZ4S7S14 
and media optimization. 3 Biotech 7(179): 1-9

35. Ray J, Jana S, Mondal B, Tripathy T (2019) Enhanced and rapid adsorptive removal of toxic organic dyes from aqueous solution using a nanocomposite of saponified polymethyl acrylate grafted dextrin with embedded nanosilica. J Mol Liq 275: 879-894

36. Rebah FB, Siddeeg S (2017) Cactus an eco-friendly material for wastewater treatment: a review. J Mater Environ Sci 8: 1770-1782

37. Sathiyanarayanan G, Kiran GS, Selvin J (2013) Synthesis of silver nanoparticles by polysaccharide bioflocculant produced from marine Bacillus subtillis MSBN 17. Coll Surfac B: Biointef 102: 13-20

38. Selepe TN (2017) Characterization of selected microbial species for bioflocculant producing potential and comparison with traditional flocculants in industrial wastewater treatment. PhD Thesis, University of Zululand

39. Shahadat M, Teng TT, Rafatullah M, Shaikh Z, Sreekrishnan T, Ali SW (2017) Bacterial bioflocculants: a review of recent advances and perspectives. Chem Eng Sci 328: 1139-1152

40. Sharma V, Kaur T, Bridle H, Ghosh M (2017) Antimicrobial efficacy and safety of mucoadhesive exopolymer produced by Acinetobacter haemolyticus. Int J Boil Macromol 94: 187-193

41. Shi S, Du J, Kang D, Chen X, Qu C, Yu T (2018) Study on fracturing flowback fluid treatment technology for shale gas in Yangzhou. IOP Conference Series. Ear Environ Sci 121: 052002

42. Siriwat P, Tiedt S (2019) World wildlife fund (WWF). Environ Sci J 34: 156-164

43. Sun P, Hui C, Bai N, Yang S, Wan L, Zhang Q, Zhao Y-H (2015) Revealing the characteristics of a novel bioflocculant and its flocculation performance in Microcystis aeruginosa removal. Sci Rep 5: 17465

44. Tan K B, Vakili M, Horri BA, Poh PE, Abdullah AZ, Salamatinia B (2015) Adsorption of dyes by nanomaterials: recent developments and adsorption mechanisms. Separ Purif Technol 150: 229-242

45. Verma AK, Dash RR, Bhunia P (2012) A review on chemical coagulation/flocculation technologies for removal of colour from textile wastewaters. J Environ Manage 93: 154-168

46. Wan C, Zhao XQ, Guo SL (2013) Bioflocculant production from Solibacillus silvestris W01 and its application in cost-effective harvest of marine microalga Nannochloropsis oceanica by flocculation. Bioresour Technol 135: 207-212

47. Xia X, Lan S, Li X, Xie Y, Liang Y, Yan P, Chen Z, Xing Y (2018) Characterization and coagulationflocculation performance of a composite flocculant in high-turbidity drinking water treatment. Chemospher 206: 701-708

48. Xiao X, Sun Y, Liu J, Zheng H (2021) Flocculation of heavy metal by functionalized starch-based bioflocculants: characterization and process evaluation. Separ Purif Technol 267: 1-13

49. Yan Z, Peng L, Deng M, Lin J (2020) Production of a bioflocculant by using activated sludge and its application in $\mathrm{Pb}(\mathrm{II})$ removal from aqueous solution. Open Chem 18: 333-338

50. Yang Z, Yang H, Jiang Z, Cai T, Li H, Li H (2013) Flocculation of both anionic and cationic dyes in aqueous solutions by the amphoteric grafting flocculant carboxymethyl chitosan-graft-polyacrylamide. J Hazard Mater 25: 36-45

51. Yu L, Tang QW, Zhang YJ, Chen RP, Liu X, Qiao WC, Li WW, Ruan HH, Song XA (2016) A novel Fe (III) dependent bioflocculant from Klebsiella oxytoca GS-4-08: Culture conditions optimization and 
flocculation mechanisms. Sci Rep 6: 34890

52. Zadja M, Aleska, Aleksander-Kwaterczak U (2019) Wastewater treatment methods for effluents from the confectionery industry - an overview. J Ecolog Engine 20(9): 293-304

53. Zaki S, Farag S, Elreesh G, Elkady M, Nosier M, Abd El Haleem D (2011) Characterisation of bioflocculant produced by bacteria isolated from crude petroleum oil. Int J Environ Sci Tech 8(7): 831-840

54. Zayed MM Abu Tawila, Salmah I, Salem S. Abu Amrc, Emad K. Abou Elkhairb (2019) A novel efficient bioflocculant QZ-7 for the removal of heavy metals from industrial wastewater. RSC Adv 9: 27825- 27834

55. Zhang C, Cui Y, Wang Y (2012) Bioflocculant produced from bacteria for decolourization, Cr removal and swine wastewater application. Sustain Environ Res 22: 129.

56. Zhao H, Liu H, Zhou J (2013) Characterization of a bioflocculant MBF-5 by Klebsiella pneumonia and its application in Acanthamoeba cysts removal. Bioresour Technol 137: 226-232

57. Zhao C, Zhou J, Yan Y, Yang L, Xing G, Li H, Wu P, Wang M, Zheng H (2021) Application of coagulation/flocculation in oily wastewater treatment: a review. Sci Total Environ 765: 1-17

\section{Figures}




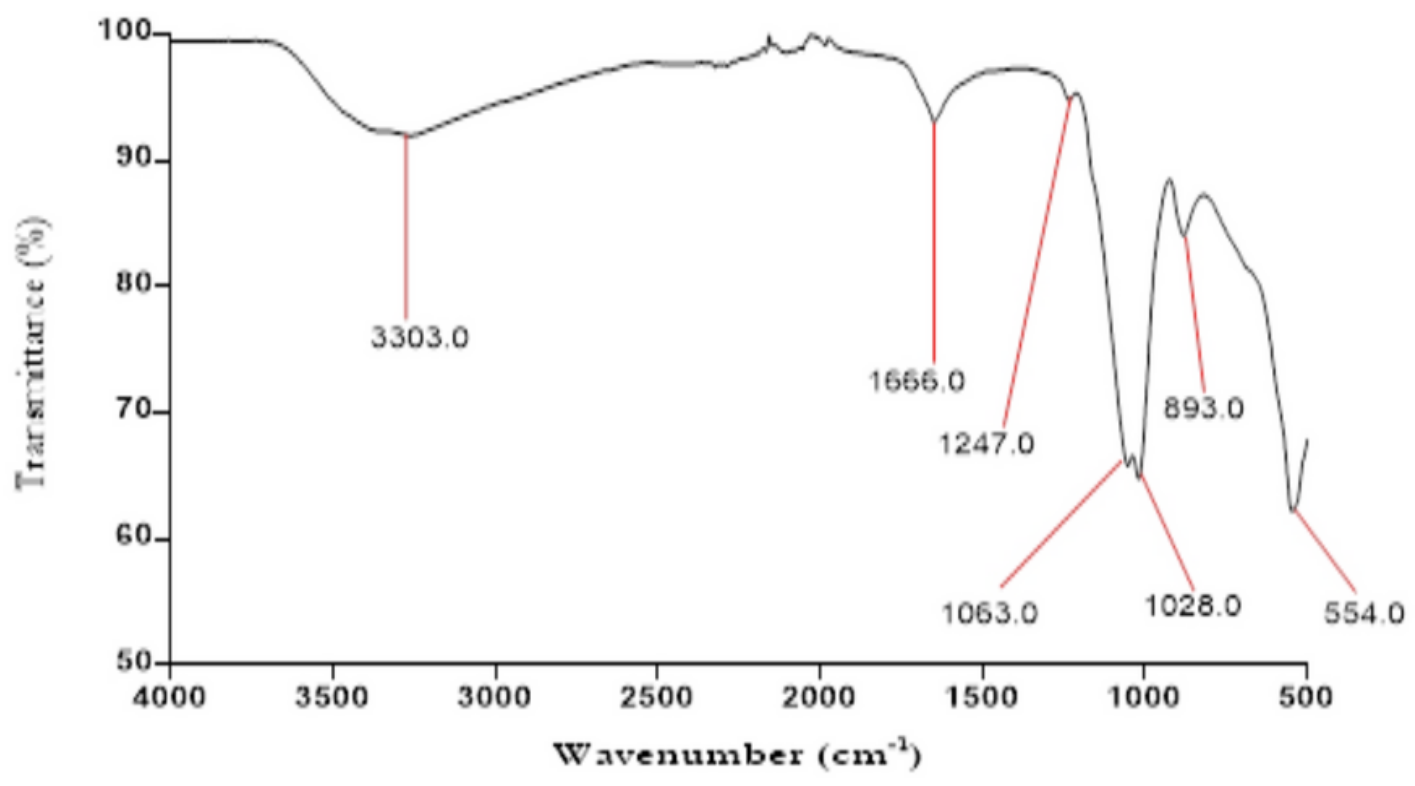

B

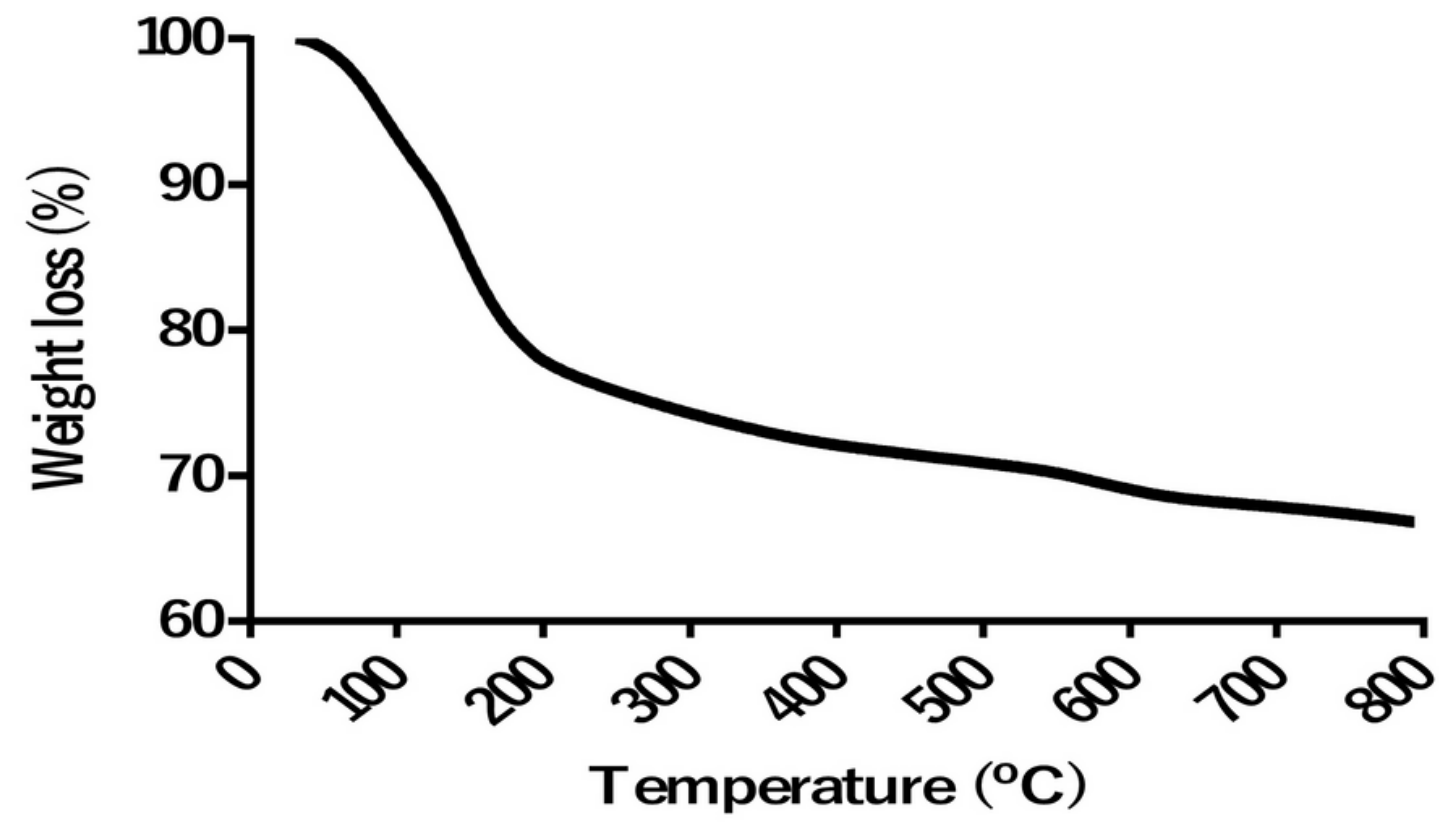

Figure 1

FT-IR spectrum (a) and TG analysis (b) of a purified bioflocculant. 


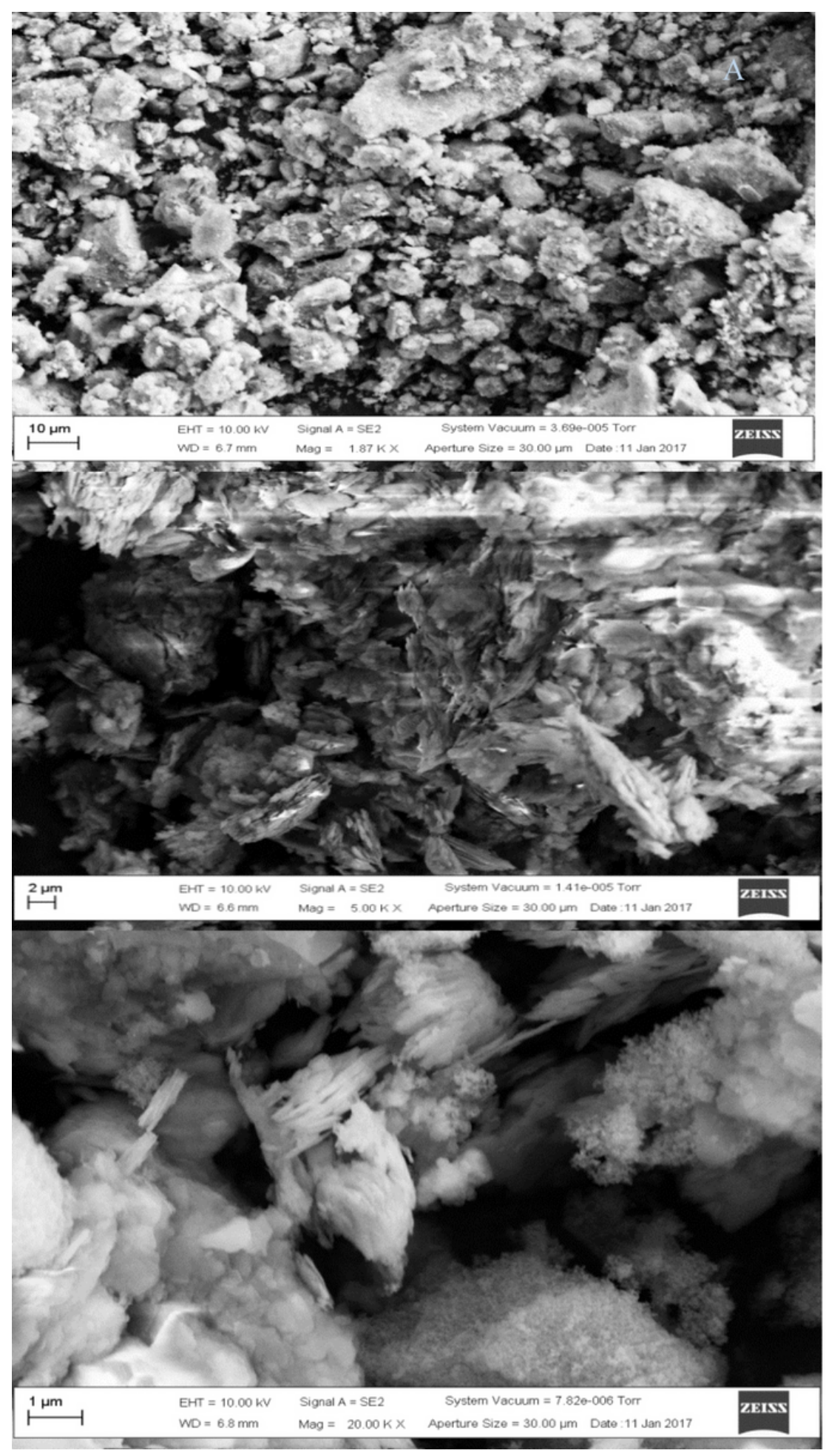

A

B

C

Figure 2

SEM images of a purified bioflocculant (a), kaolin particles (b) and flocculated kaolin particles (c). 

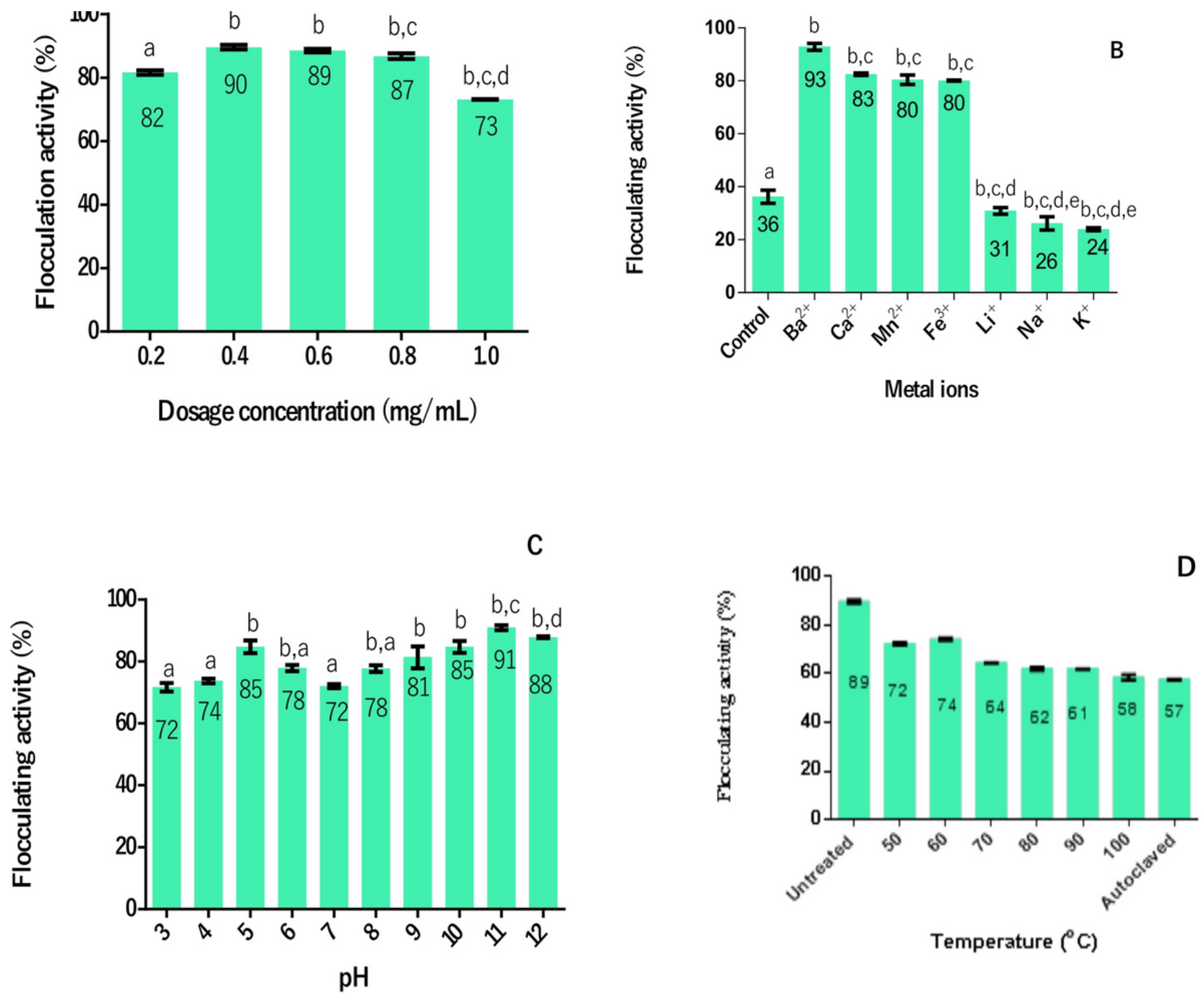

Figure 3

Bioflocculant dosage concentration (a), metal ions (b), pH stability (c), and heat stability (d) analysis. 


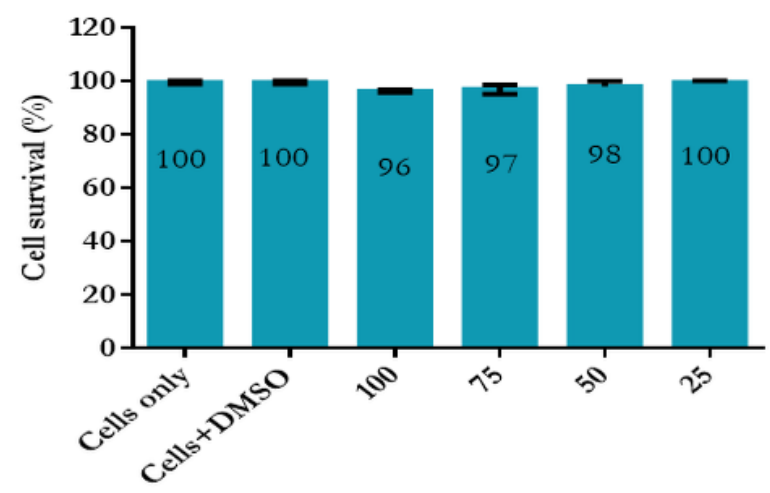

Concentration $(\mu \mathrm{g} / \mu \mathrm{L})$

B
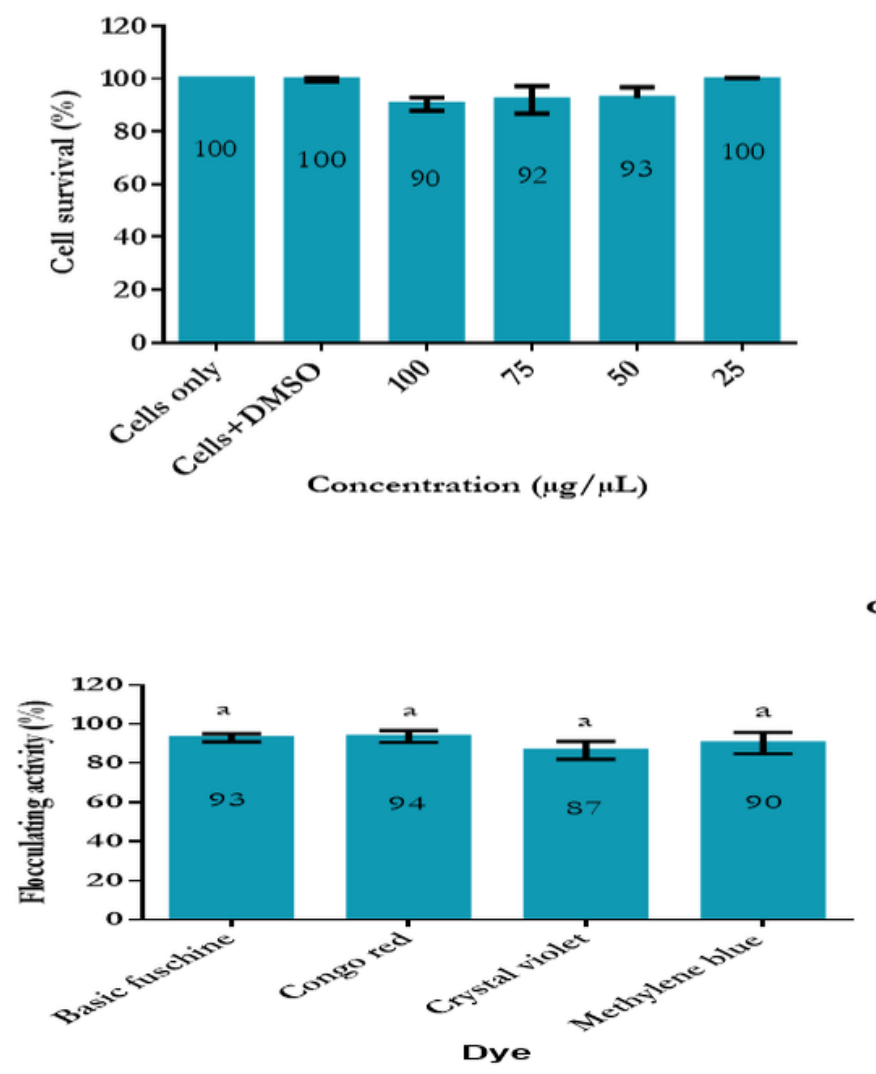

\section{Figure 4}

Cytotoxicity analysis of a bioflocculant using HEK 293 (a) and MFC 7 (b) cell lines and dye removal potential of a bioflocculant (c). 